\title{
Heavy hitting: concussions and safety law
}

I t's a simple question: Might occupational health and safety law be the foundation to compel Canadian sports associations and leagues to change their rules to ban actions that cause concussions, such as hitting in hockey, or heading the ball in soccer?

Possibly, legal experts say.

But they're quick to add that there appears to be little appetite to use safety legislation as a vehicle through which to achieve advances in sports safety.

It's possible that the rules of any sport could require revision on the grounds that occupational health and safety law applies to the field of play, says Robert Smithson, a labour and employment lawyer with Smithson Employment Law in Kelowna, British Columbia. "Generally speaking, I think the prohibitions contained in worker's compensation legislation against exposing your workers to danger - to the risk of injury in the workplace - could well be a very substantial leaping off point for the assertion that sports leagues or sports teams that knowingly place their players in danger of injury ... either be held to account or have to change their practices."

But compelling such change would be a challenge because defenders of hockey and other sports typically fear the consequences of changing the game, says Alfred Kempf, a lawyer specializing in labour and employment law at Pushor Mitchell in Kelowna. "Hockey is sacred to all of our hearts as Canadians, more than any other sport, probably, and I think that may play a part in it. We don't want to mess up the game. Any province that attempted to go there would probably feel a lot of pressure not to go there.'

While using occupational health and safety legislation to affect change in sport is theoretically possible, "I don't see it working in practice," Kempf says. Each province in Canada is responsible for occupational health and safety law, which would make it difficult to achieve national, coordinated action, he adds. "I guess to extend that you'd have to look at all of the America teams, too."

One outcome of a spate of lawsuits against the National Football League (www.cmaj.ca/lookup/doi/10.1503/cmaj .109-4243) could be demand that occupational health and safety law be used to compel action, says Travis Leach, a sports and entertainment attorney at the Jennings, Strouss \& Salmon law firm in

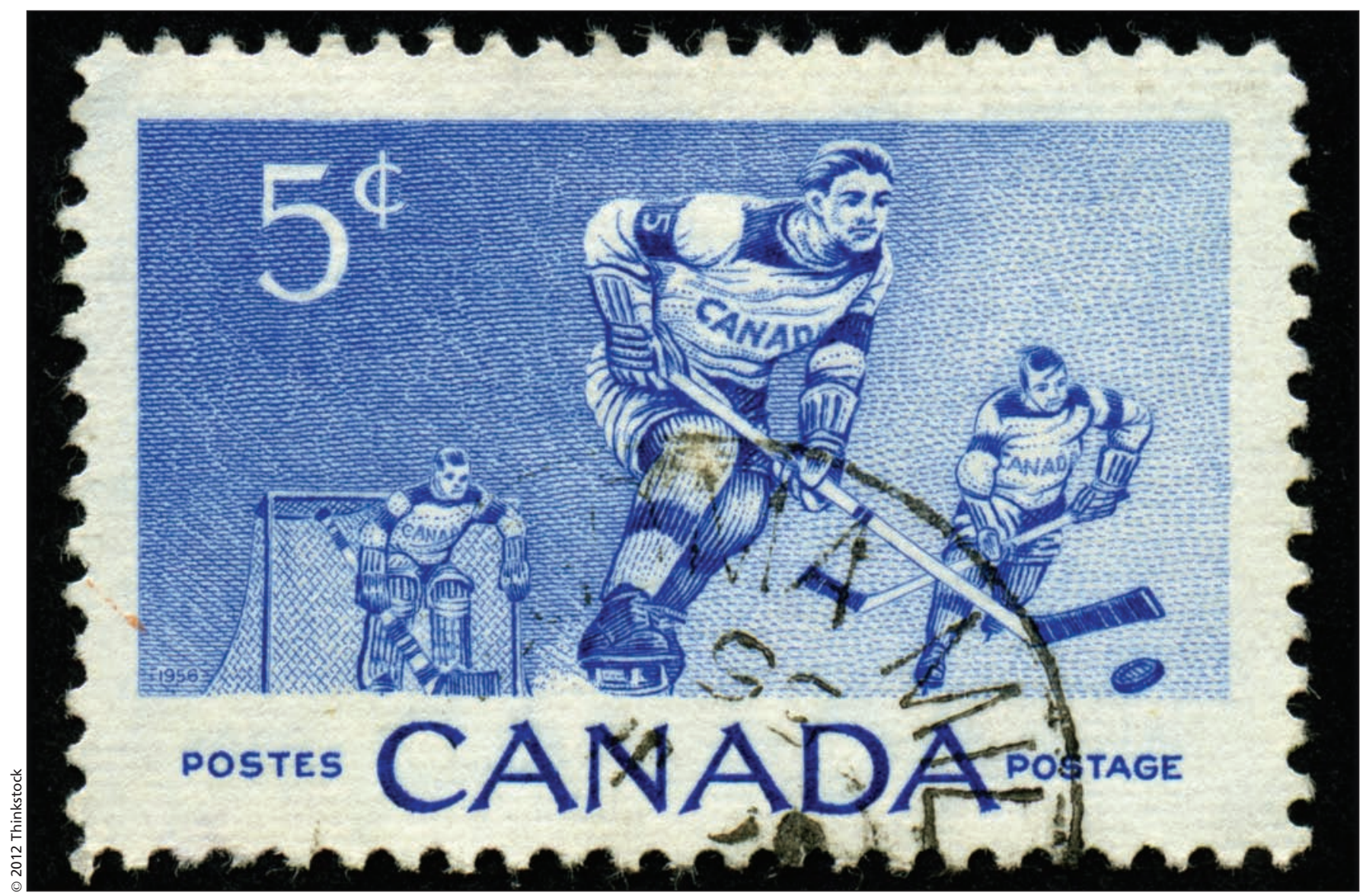

Hockey is practically sacred in Canada, so using occupational health and safety legislation to change how it's played could be a tough sell. 
Phoenix, Arizona. But it hasn't been a focus to date, he adds.

Equally problematic is that occupational health and safety legislation typically does not deal with such issues as the rules of sport and "the essence of the games themselves," Hilary Findlay, cofounder of the Sport Law \& Strategy Group in Toronto, Ontario, and an associate professor in the Department of Sports Management at Brock University in St. Catharines, Ontario, writes in an email. "Other avenues of redress are likely more appropriate," including union lobbying and negotiating, public pressure, and lawsuits by players aimed at sports leagues.

Smithson forecasts that other forces, rather than occupational health and safety law, will soon force sports leagues and associations to move forward with changes aimed at reducing the incidence and consequences of concussions. "I think the rumblings that you're starting to see in the US [United States], particularly against leagues like the NFL [National Football League] by former players, I don't think that's going to go away," he says. "It has to happen sooner or later that the occurrence of head injuries and the long-term effects of head injuries to professional athletes cease to just be kind of an individual curiosity and they sort of coalesce into some form of a larger action."

Evidence of a link between concussions and chronic traumatic encephalopathy, along with national angst over the fate of hockey superstar Sidney Crosby, has prompted calls for an end to hitting in the sport (www.cmaj.ca/lookup/doi /10.1503/cmaj.112081). Meanwhile, widespread publicity about concussions has prompted a slow shuffle of Canadian youngsters out of contact hockey and compelled one critic to contend that Hockey Canada's failure to implement stricter anticoncussion measures constitutes nothing short of "child abuse" (www.cmaj.ca/lookup/doi/10.1503/cmaj. 109-4167).

The growing evidence of the consequences of concussion has also led to the spate of class action lawsuits against the NFL, in which plaintiffs allege that the league has "mythologized violence" by glorifying the "brutality and ferocity of NFL football, by lauding and mythologizing the most brutal and ferocious players and collisions, and simultaneously propagating the fraudulent representation that 'getting your bell rung,' 'being dinged' and putting big hits on others is a badge of courage and does not seriously threaten one's health" (http://nflconcussionlitigation.com/wp -content/uploads/2012/01/NFL-Master -Complaint1.pdf). — Michael Monette, CMAJ

CMAJ 2012. DOI:10.1503/cmaj.109-4244

Editor's note: Second of a two-part series.

Part I: Heavy hitting: concussions and the courts (www.cmaj.ca/lookup /doi/10.1503/cmaj.109-4243). 